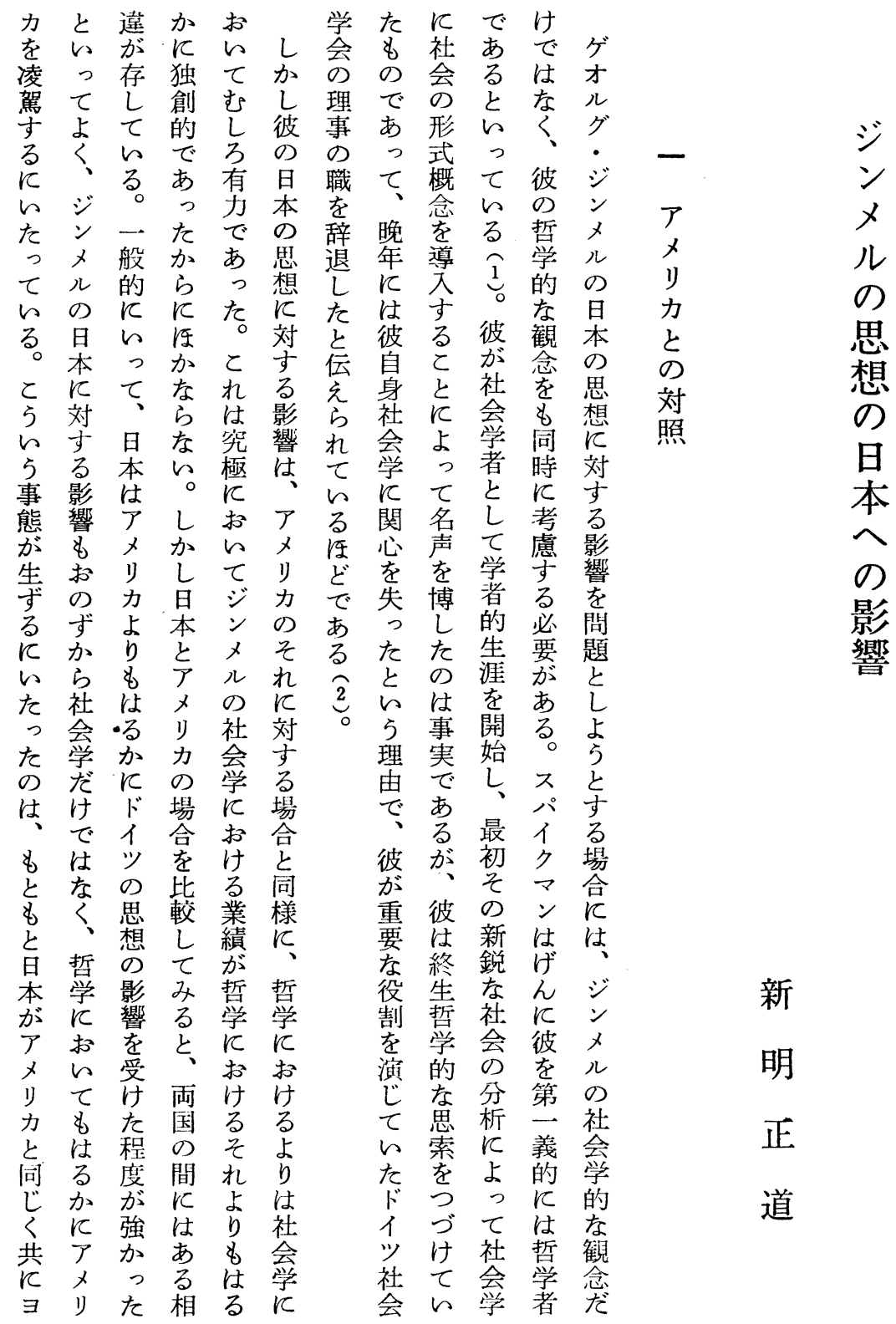




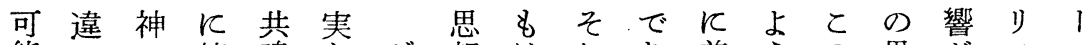
能らで值鳴なジ想はれあ普 5 の思がス口 性さみ守し弟ン壮るはっ及飞変想顕や”

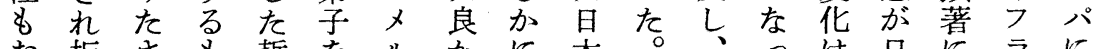

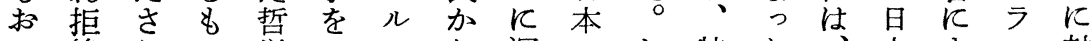
の絶れの学との机深のし特た、本さン対 ずさてが者の覀く思かにの政でれスし

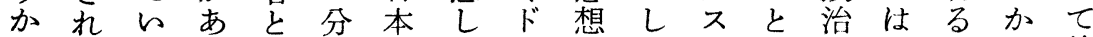
らるるる評野のかイ界明へ時的压らら後 稀有了。論飞哲机高飞治ンを保と5科進 薄様メア家見学日の君憲 ででリメの出に本思臨法、じ主どな的の ああカリ間す対に想すがのく義最り知地

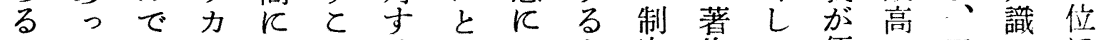
のてはではとるっいよ定作て優のアのに

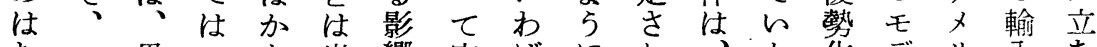
むと思とな出響容ばにれ、た化デリ入节 しの弁れり来は易馴なた自のしルカに ろ状はにの先汇染っ一染でてとで努前

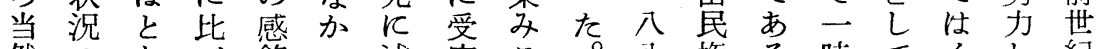
然の吕心銘つ述容と公権る 時て でもくるをたべしんて九論。勝歓ギての あと懷と与得での年と利迎り来半 るで疑 ジえしょるし歴以の本をさスた壮 と

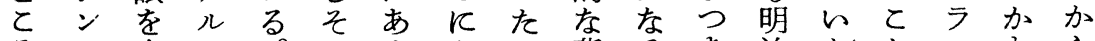

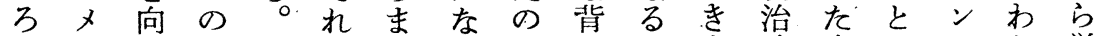

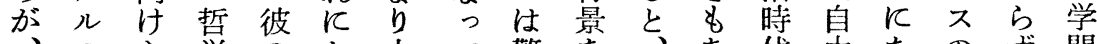
、のら学のし大て驚を地あ代由なのす問 日哲れの 哲てききな゙っの主っ思、的

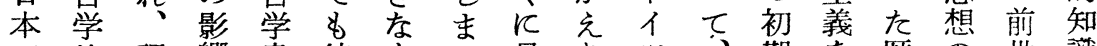
で的理響書彼\&足 り は思論はののの社の続に粉史附紀の 反想的絶大奥でのなる思々 は砕的録の開 対がを無部深なでいな想邦イし事以終拓 反親思で分らくあをらが訳ギ、情上り て近考あが論、ると壮とせリ軍がど着 5 感さる邦理ジ。で、的らス国らはろ手

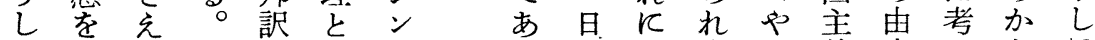

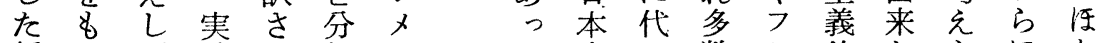

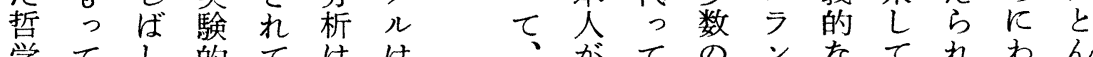

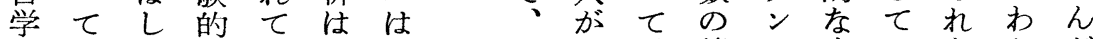
を迎壮から少結やア登読ス支いなが゙

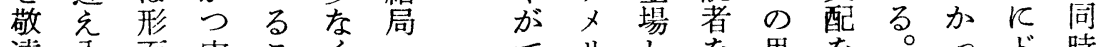
遠入而実とく—てリしを思を。っド時

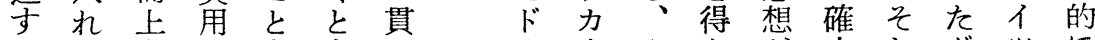
るら学的\& \&立人やたが立しドツに

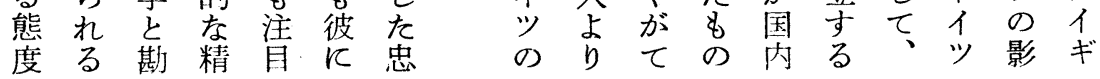


思は者作一法的京後会ののジので配が 想旦がが九論な都学社入シジあいて全

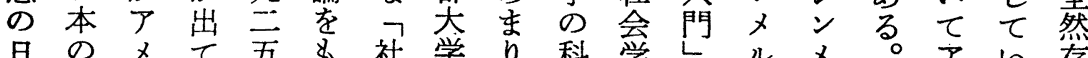
日のメて吾\& 社学 り科学

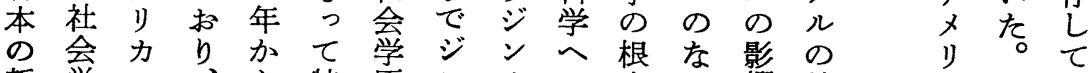
哲学の、ら 特原ンメの本か倠社学 ジ

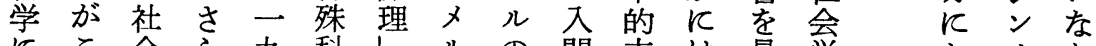
にこ 会ら笛科しルのの門方は最学的メか

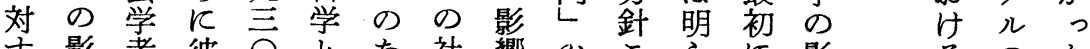

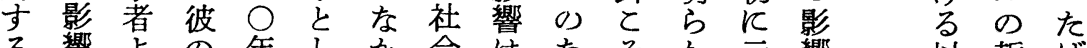
る 影響 響よ\&場間のジを著で社てつ をつはをと社ン効反は完会らい

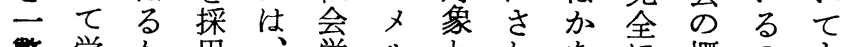

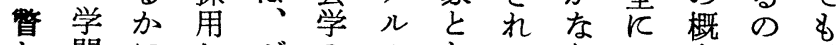
し問 $儿$ ～ジの のして て的多た $た$ 立著てい濃綜怘去 みKく数メ場作詳な厚合お夕会 るらの冊儿ををを細らと社らッお とか影のの積広からジ会てケい と響社社極沉つ 5 学 ジンて

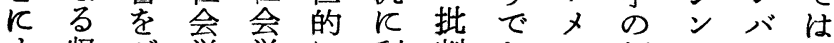
す收 ジ受学に利判あ几傾メ、と

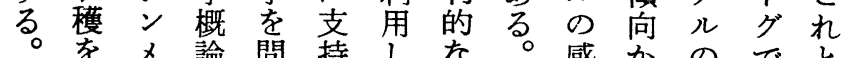
をメ論問持しな。感かので 可儿書題索 講と华ら見あ同

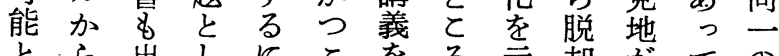

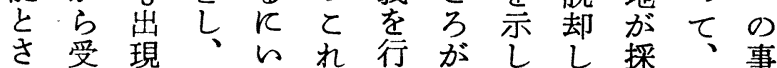

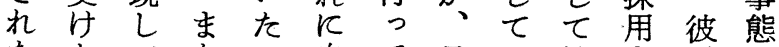
たたてたっ自て日的はさ仿が かて的はて主打本た的一認

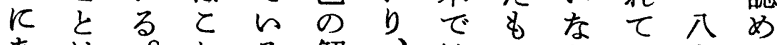

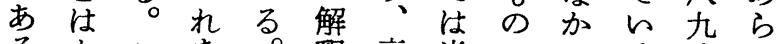
るたとを。粉高米でっる。公れ がしの批そを田田あた。年た 最で期し判允㠰堡庄 る

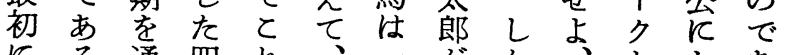

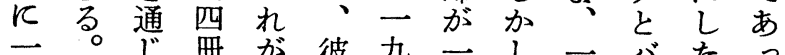
- 。

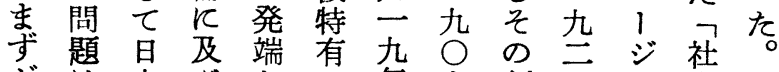
ジは本占との年七割二エ会了 ン最の学な厳の年に年ス学入

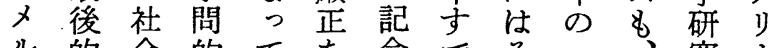
儿的会的て念でそ榙究力 のに学著、方塔に社そ究无

の が

影郎市 をとド 生点 た ンの の 思 8 想 ᄃ 0 51 新 しゲし た $几$ 事の学 情 そ 派 かれな b $飞 ら$ 考対 ば 充抗 何 る 寸で 之. 品声 な が ら出 受 导来 け ᄂ な付 如 的 偶 2 然た 5 で と はせ手 な点傾 2 日 向 た本吕 の飞支 
のはてたけお接を響がそにドデテ なべデとるい的基が、れとイルン先

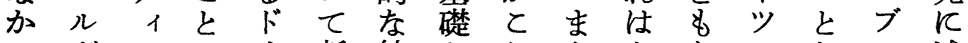
でグルでイ 新結とれたたな述

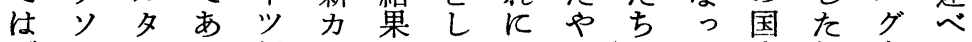

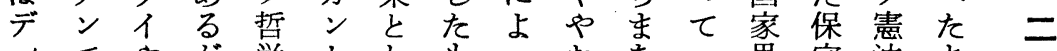

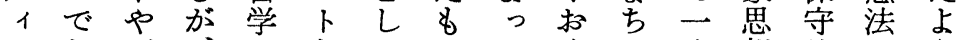

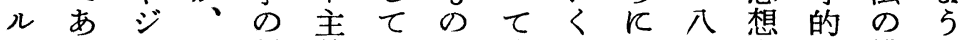

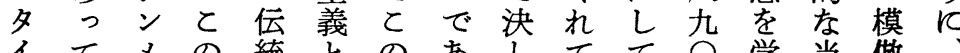
イてメの 統 と の あして て ○学当做 が、儿変女 そ哲ってフ日年問時光日 ジデに化明の学た弱ラ本か的のあ本儿

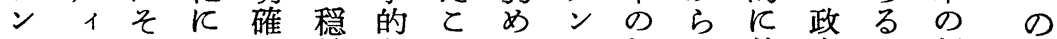
メル の と な健な と学哲一普府琞哲哲

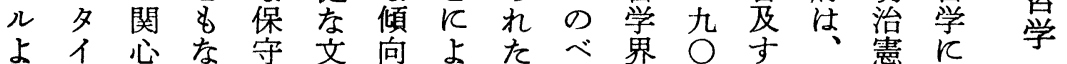

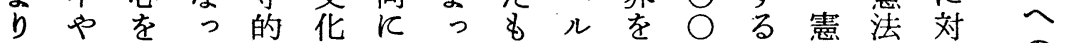

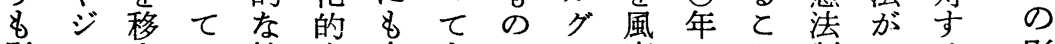

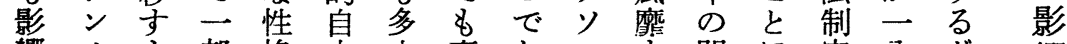

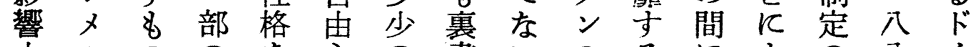
力ルの の を主の 書的の る にの\&日失義変さ哲に早っ準九产

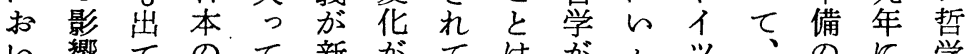

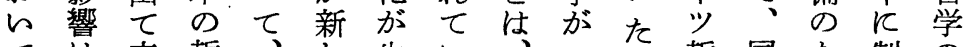
て 来哲、し生い哲。国た制の

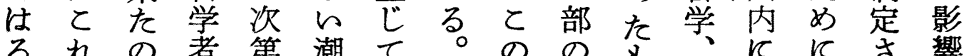
るれの 者第 潮て 。 の の \& 、 に かにでのに流来し時学の特お、れ が にくあなとたが期者でにけだて影

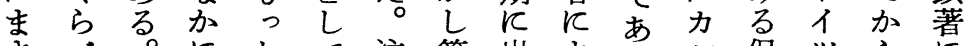

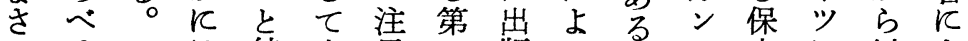
っるしは純人目一版っ守に上さ て か一粋気さ次さて一と的多後れ

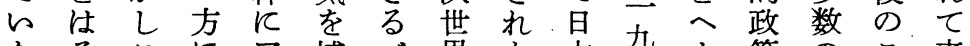
たるとにア博年界た本九策のて来

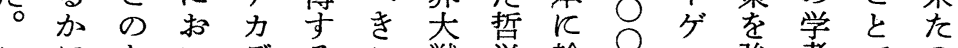
こにならでる戦学輸年ル強者での

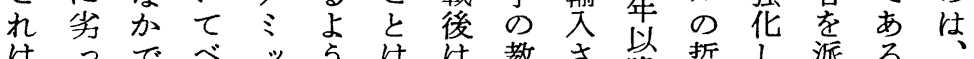
デて

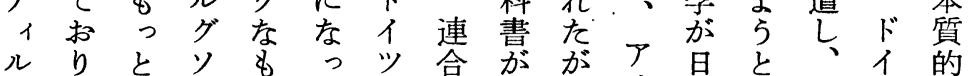
タ り 、 ⿱

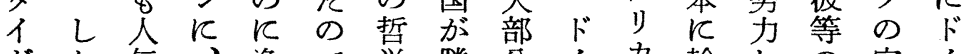
がか気、浄で学勝分イ力輸しの官イ

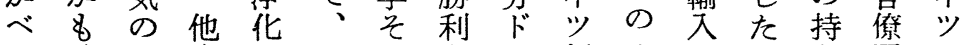
儿後あ方さ五のを哲実せがち国の リのつに本\&得ツ学角ら、帰家ヴ 大 音の た 
ずゲ 受 東\&ュュ゙学り 欧るしが゙問者 影学

、1 け 京の 夕 こ

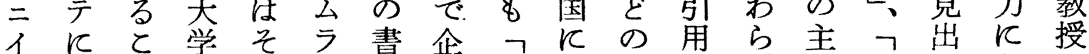
子関と の の

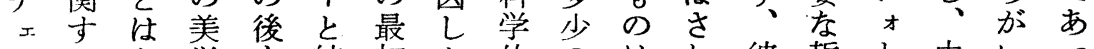
のるな学㫊初た的のはれ彼哲 ! 中いっ ᄀ著か教あびの経し反絶がた ツ作つ授らつ翻済で響人㐫影的ンはあの

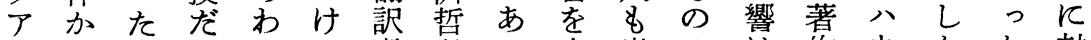
ラらがっれて者学っ生出のは作ウたた対

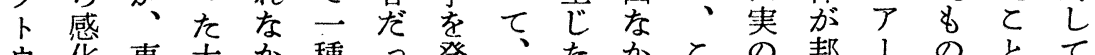

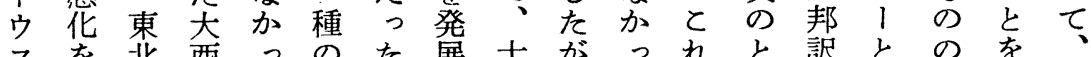

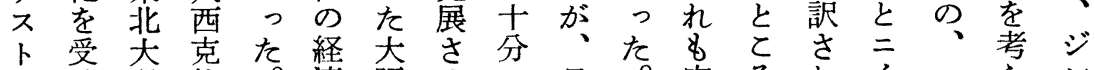

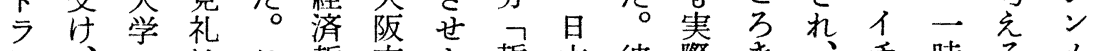
は、の沬と哲市よ哲本彼際き

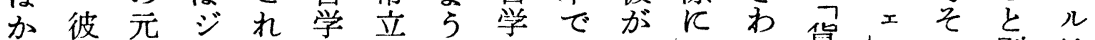

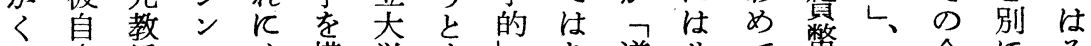

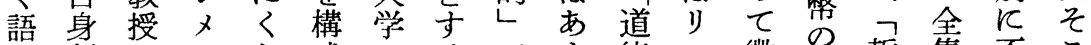
り新でルら成のるでま徳ッ微哲哲集不と しカ カ

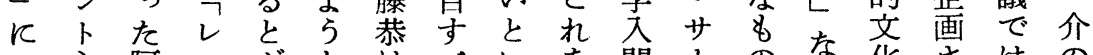

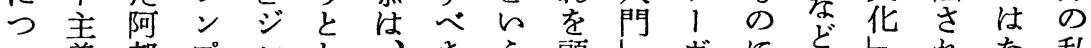

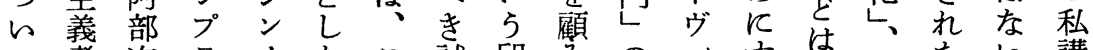

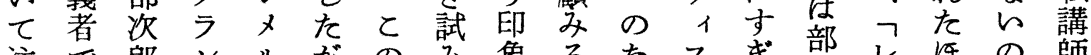

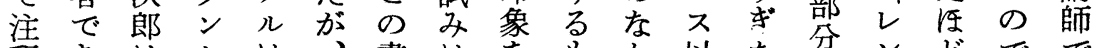

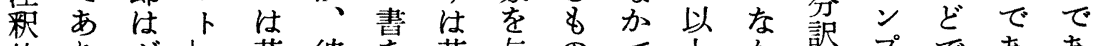
的り ジし 芸彼荐与若ので上か訳 プでああ な人ンを術の高午えは主のっっでラあっ 㶳格メ 翻哲 試

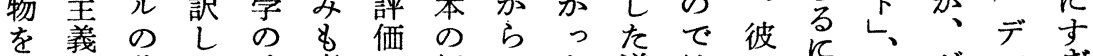

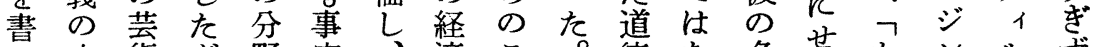

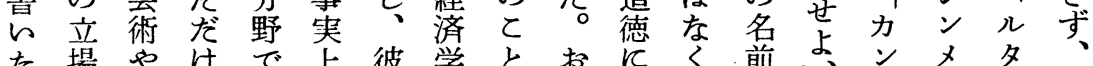

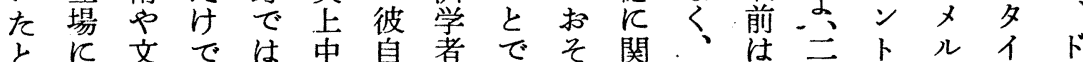

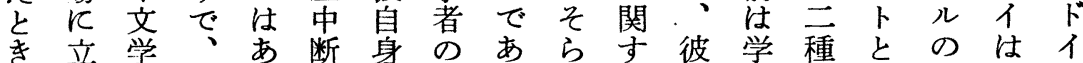
にっにこるせ はて関狆成らン意 $ら と$ 相弟的 81 合本

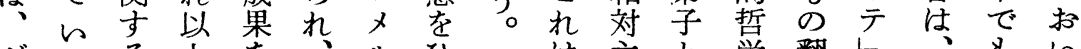

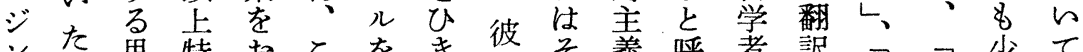

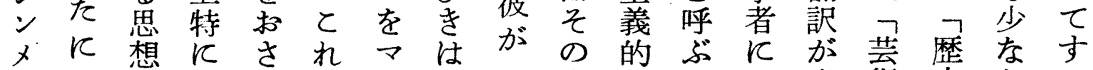

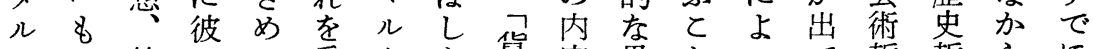
の加特のて受ク在貨容思とって哲哲らに

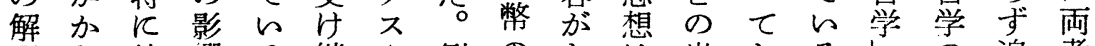
秎わ彼響る継や例のあ壮し出しるしの追者

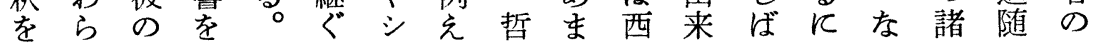


てり事とを人物子れ合神のト証彼まま大 八は実し邦、の哲て 理の 哲で明のたしい イ強でて 訳 ジ表学拈性表学\&しし論 ジかて

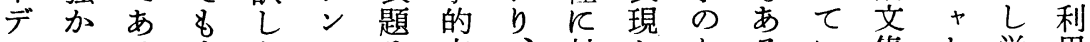
ッっる大だそ文、対となる集的学用

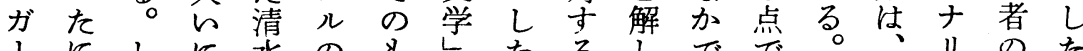

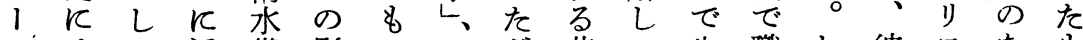
のせか活幾影のフが非て生職し彼スな8 実よし、躍 态響 8 日

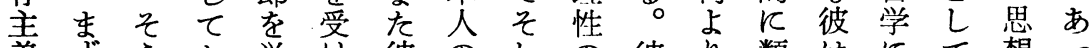
義す 5 打挙け彼のれ、の彼り類は年て想っ

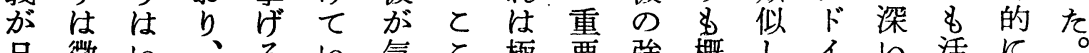
日微 本弱っ そ と る 紹あ生がのて非あるなる生をてと

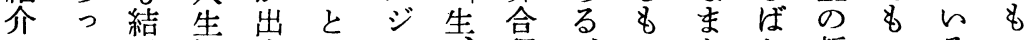

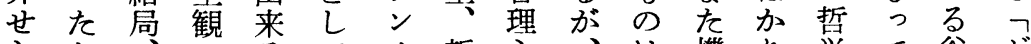
らと文年主、は機り学て谷 れ見ジな皇学義彼械で者ら川ン

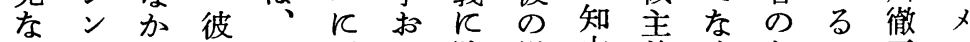

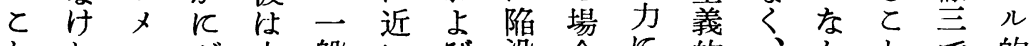
れ $九 シ ゙$ 本般ら没合に的、かとで的

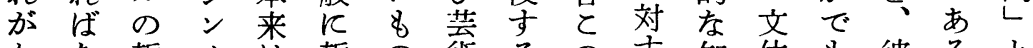
かな哲メ沬哲の術るの知体\&彼万と なら学儿社学の知る 力特が

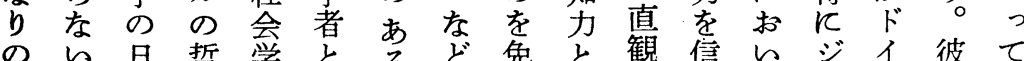
の ら

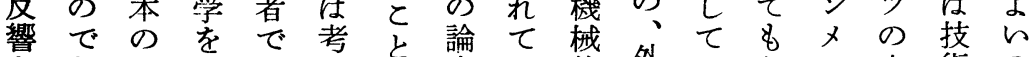

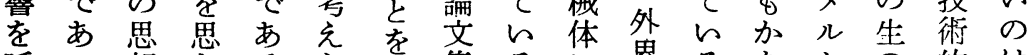
呼っ想わるらら暗集る惢界るなと的は

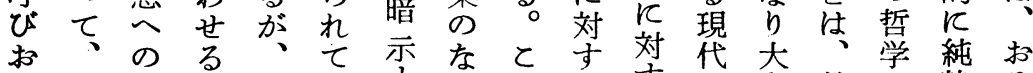

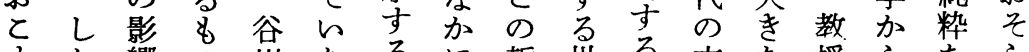
すか響の川なるて哲批る文な授らなら

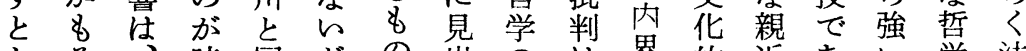
と之、時闹がの出の壮界的近あい学法 \& れ と光、とさ解常の、な性る 影書 政 にはメしょ゙ジんれ明識心状をを響をを大

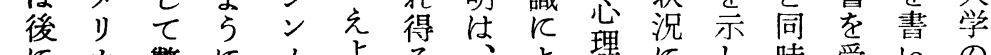
一、瞥にメ方る 段生に見 ジル 5 㤎感っ 対対て

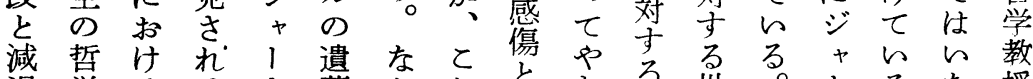

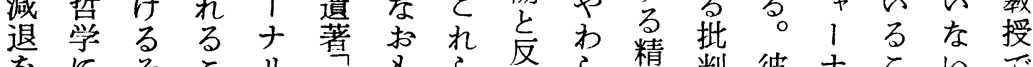

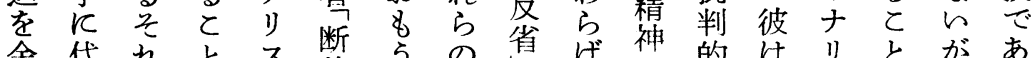
余代 れ 
上 視

万さ

的加

なてし

3 r $r$

てた

来 壮

た

ジの今

ン 社 世

メ 会 紀

儿学 が

の㤌

名飞じ

前わ军

はかる

$\rightarrow r r$

八 日

公本它

年 社 次

岸会第

本学 $r$

能者変

武 の 化

太関 ᄂ

の忍た

社を妾 と

会导

学致わ

டじけ

のめ、第

な、等

か ジ次

でン 世

社 又界

会儿大

学の 戦

者名 後

と 前 $反$

七学

は在と

じ宣、

め伝久

てさし

紹れ
あ乞と彼東ま亿変各す学

ののの京だッ化大るにジ

自当体大㙏学と対

由時系学イのと内としメ

訳飞は教ツよ文でろて

もは明授の5な崇で例が

公了施な゙社な外社

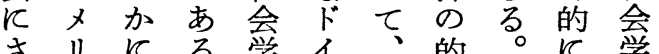

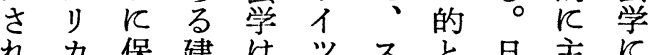

狆力保建注

的社主愿をオンれのしし

た会義吾下、サる社てて界

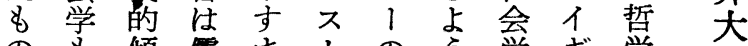

の\&傾需ま卜の5学ギ学戦

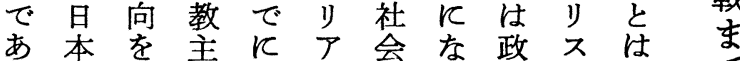

っ $K$ 帯義はの学引府々打で

て導びとな社にてのうっ 入て ב会対加政

てさらンて学守ら策湾

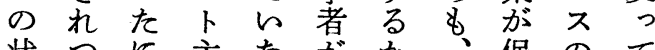

状了反主ながか、保のて

況つか義吕次つ久守影き

はあかとっ第てし主響わ

一りわをた质の義のめ

応、ら奇为注情

前ギず娶の意熱お転と大

世デ、にでさはド向にき

紀、と文市机失イし発な

のンれ混るるるわ稀

終グに 合。文れかドし響

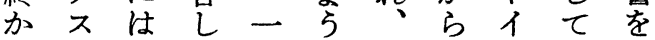

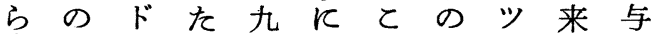

今ᄀイ—○なれ影のた充

世社 $ッ っ 0 っ k$ 響思事た

紀会かの年た代老想実と

の学ら社以のっ兔とかと

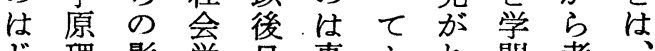

じ理影学日事シれ問考

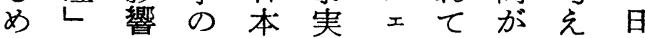

まは体のでッら政て本

で特全系社あフた府みの

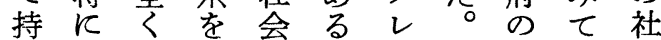

続鹳尔提学がや夺後方会

れせてし指そンろに注が

たららた導れプんよ目他

のれたがしで口とつにの

で隹市市のて值科
な

さ

れ

$=$ た

あ

二 る

ジ

$x$

ル

の

社

会

の

影

響

介る 無 


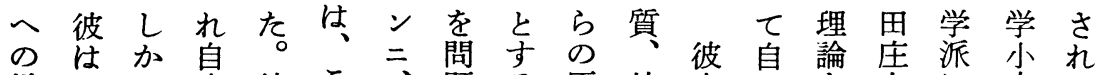
批 ジし身彼と、題る。原社自己学太态史た

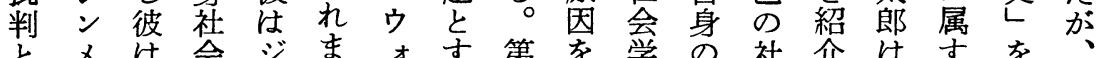

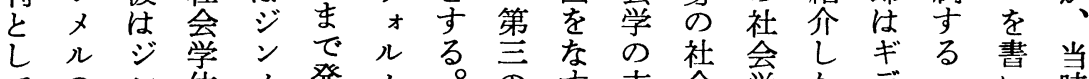

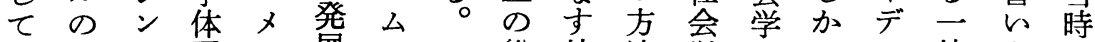
発提メ秀儿展スと総社法学のつ社たは 生唱 $の$ のさ、合会沶体体批ン会樋彼 ししが不特れ グ 考社心系系判グ学口の たたと可殊だえ会理びのをを者秀特 とよの科社 と 5 形の 学会リは的会口想一多し\& の

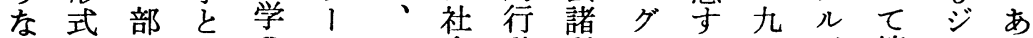
後社社分しの沶一会動科 ラるード簡ンる 者会会をてする方形学么四の単メ形

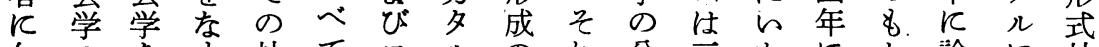

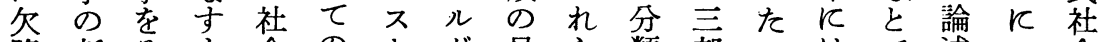
樎新そ\&会の部キド具ら類部つはで述つ会 のしの の 学部ル、体の主門たさ研しい学 あらをとを門 ラジ的発組に方ら究たての

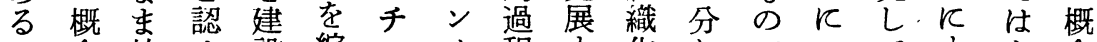
と念社め 設 綜エメ程す化れでフて す た 念

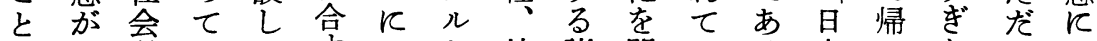
はコ学とよすすよお社諸問らる本っなオつ 十ン の れ 5 る 2 よ 会過題る

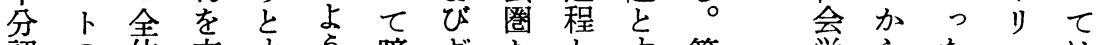

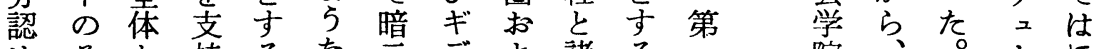

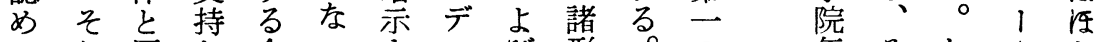

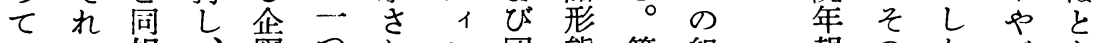
らの視、図つれン団態第組報のがん

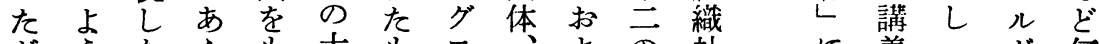
が 5 た $\&$ 大 8 ス、義二小何

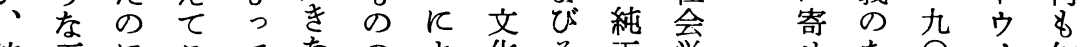

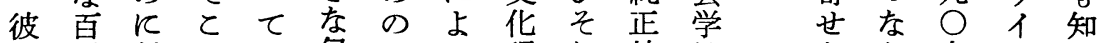

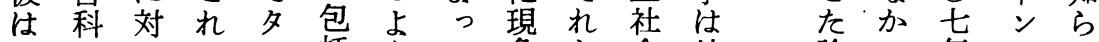
ま全して活 5 方象ら会社論で年とれ

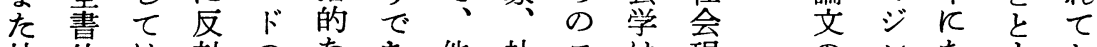

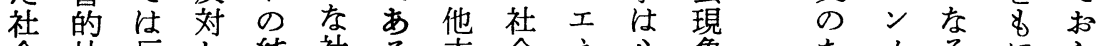

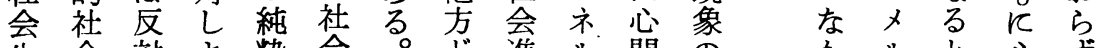
生会 対

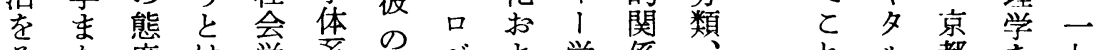
そた度は学系のべよ学係福都を九

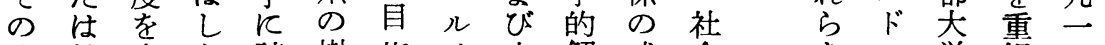
全綜表な該樹指子文解成会 基の学視三 体合明少当立!、化粎立理 基社講主年 に社しっしでた、的を走法礎会師る、 お 会た た。そ学 た 
をなて 社判世た ジにのら、張市ま的て

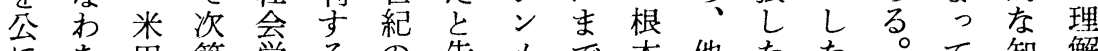
公 田第学る の告メで本他たた。て 知解

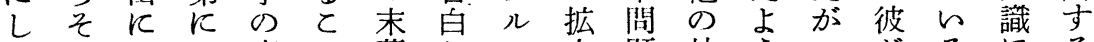

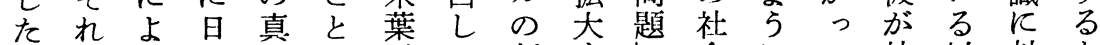

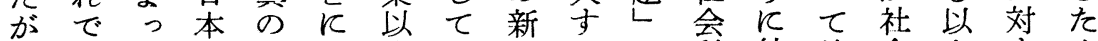
ああての意よ来ししるの科純彼会上す

こるま社味っ西る の。会がて欧の概、かと社否社

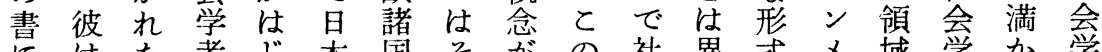

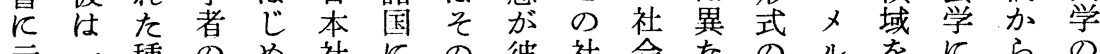

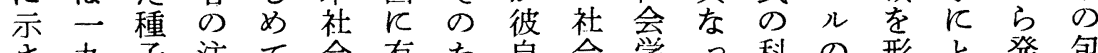

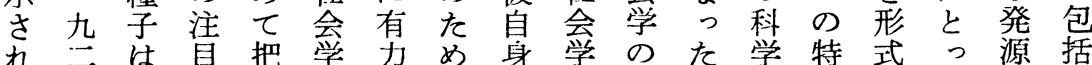

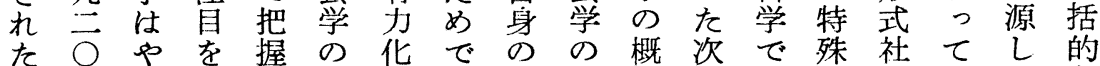
社年がひ立科しあそ概念元あ科会とたな 会籹てくれ学つるれ念壳のる学学れと体

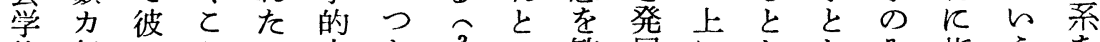

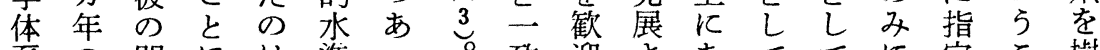

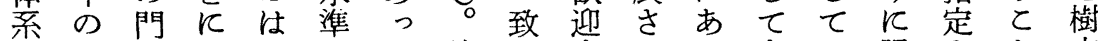

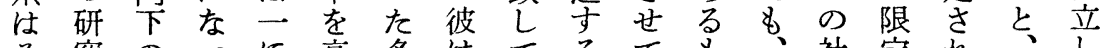

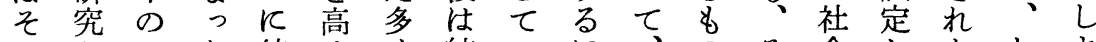
のと一た彼めく結 師思人ののるの局る躊社との学上作か

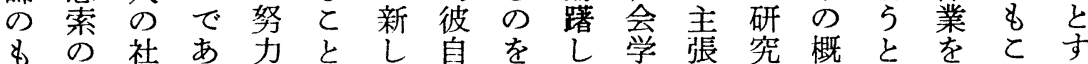
の結会る $反$ r

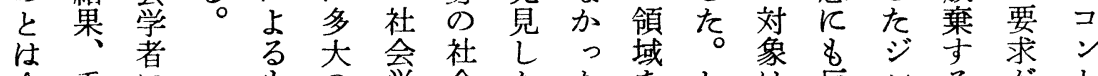

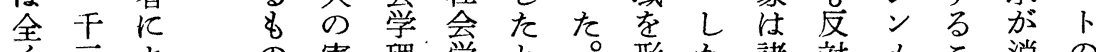

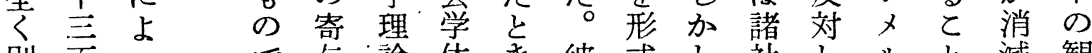
別百っで马論体き彼式し社しルと滅観 の八て あを公系、怔社会た。の留し念

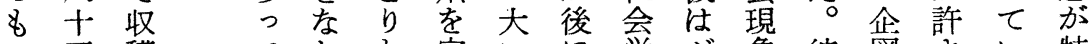
の五穫てしわ完い浮潼像図さい特 で頁さたた成に発をンの沬をれな殊

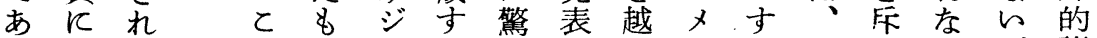

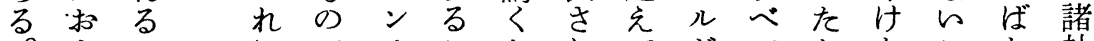

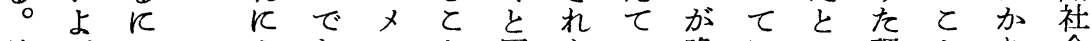

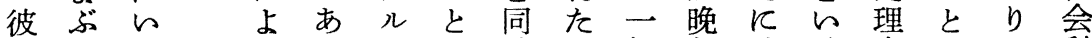
壮大たっの時一般年共社由を科 米冊ってた そ出 $r$ 論社 $r$ 通会は良学

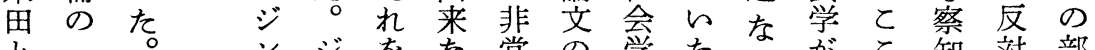

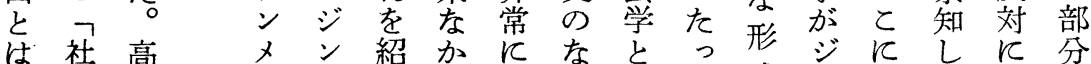
度社高会的界紹か 対学保自儿した快で学六でメるるい寺か 飞原馬身のかがに社社あル。たまつ

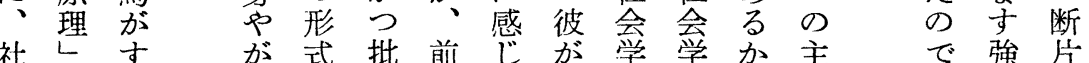




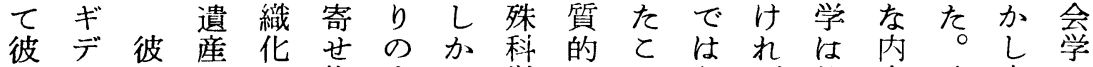
の.1はをに集すし学にとなば他容彼実の 理ンジ組沶める彼と建はくなのをは現対 論グン 織いた 思はし設明、ららす含ジ不象 をスメ化て す想とててらてない゙んン可を

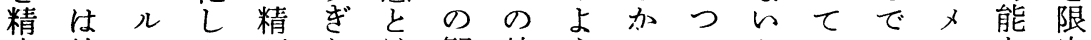
密彼かよ巧なけ観社 5 でのとのんルな定

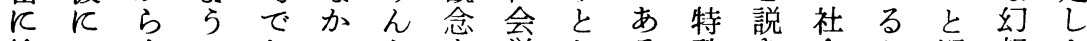

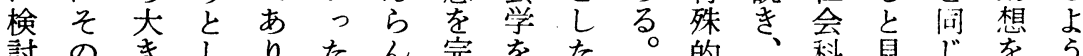
討のきした完をたた。的、科見じをら

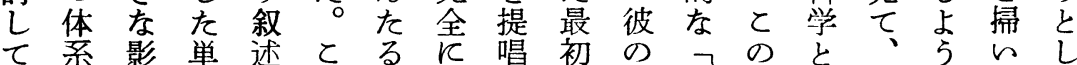

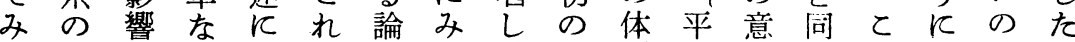
る輪をる沶理の、試系民味じれ出けジ

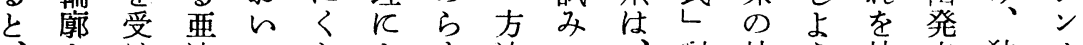

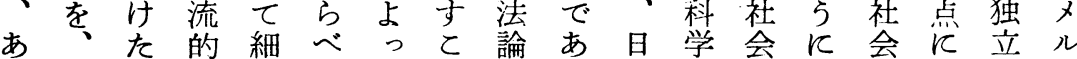
るデが学密るてと的っ本で学、学拈しの 重二他者でと特に质をあは社のにた企

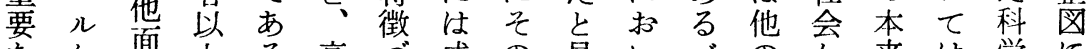
なケ面上る高づ成の見らべのか来は学に

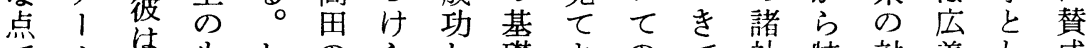

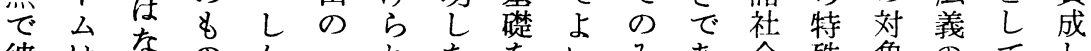

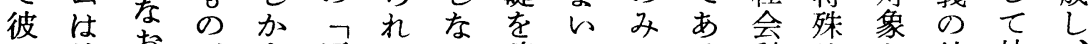
の彼ギが\& 原て か確ででる科的た社社

見に元あ彼理はつ立あはと学なる 会会そ

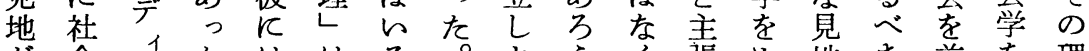

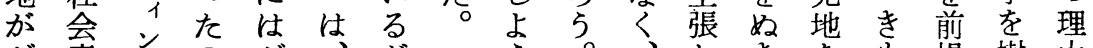

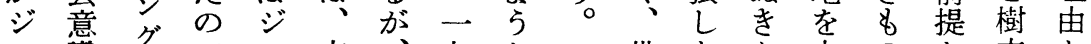

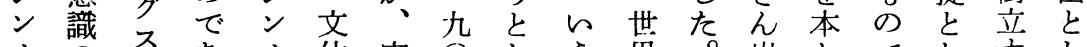

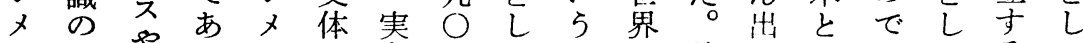
の 概 デる

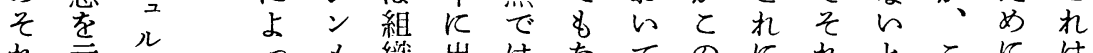

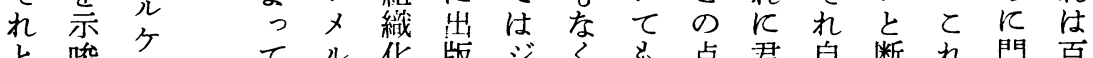
と 唆 1 て

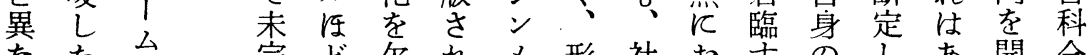
なた 台 完 ぼ尔れメ形社お沶のしあ開全

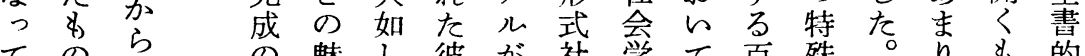
て の の 魅し 彼が社学て 百殊。 り方的 らで感势たの第会を明科的彼にの社

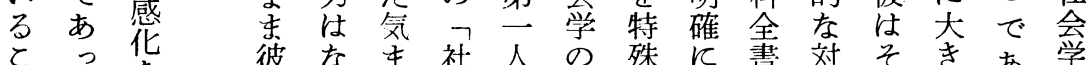

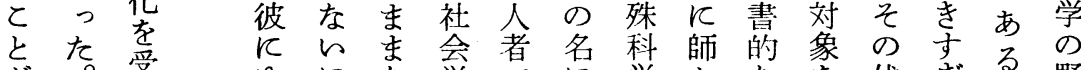

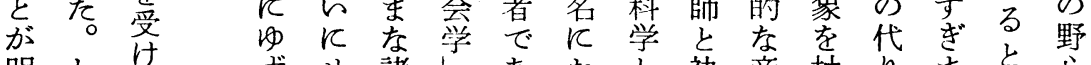

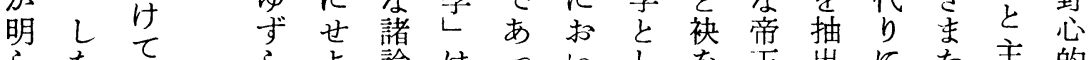

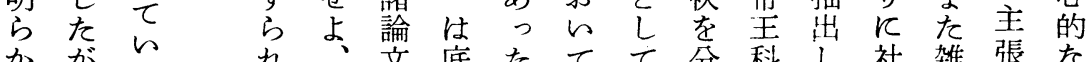
かがれて文底たてて分科し社雑張な 飞っる。組の光。特尖っ学な会多しし 
つ社約よ第史文は社束そ何れに象入な

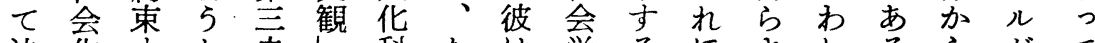

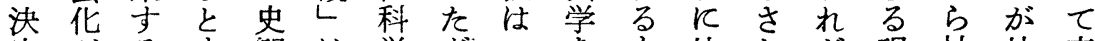
定がるす観は学だ二老も比しが現抽社来 的最一るは注、特の較つ経奥出会る と第、 $、 ゙ 二$ 三 殊と出か済を学华の

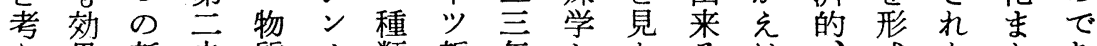

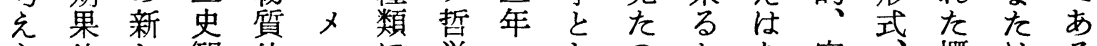

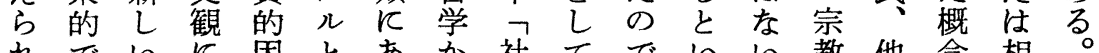
れで

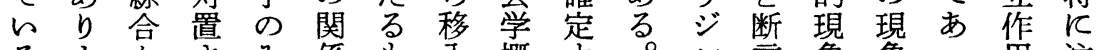
るまたさ係\& 入概卞。言象象つ用注 経たるれに的のさ論る彼メしををて をを目

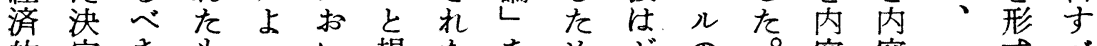

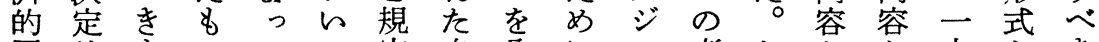
因的主のてて定自公にン考儿と方文を 子でので歴注し 然にはメえた考規の考と \& あとあ史目た科して方がえ定見5と 実と 意って 解值 け と

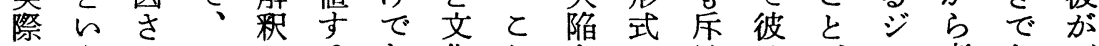

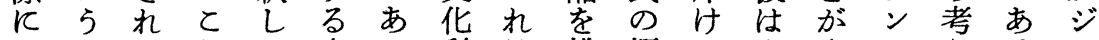

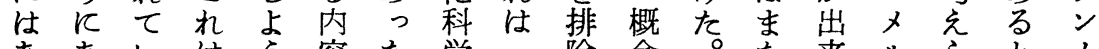

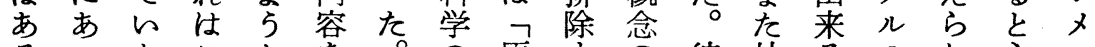

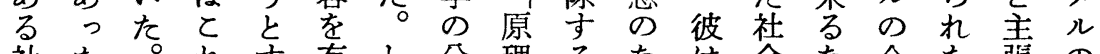
社た。方有し分理るなな会な企た張の

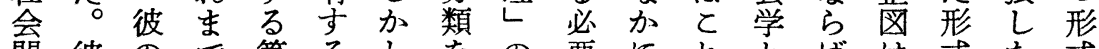

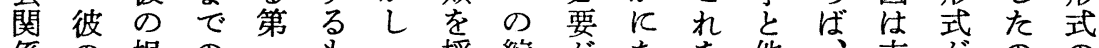
係の 根の 文一採䋶 がをを他、支がのの

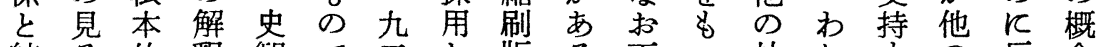
結る 的 粎 観で三し版る百っ社れ主の念

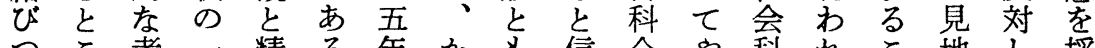

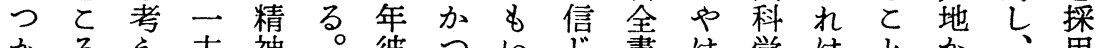

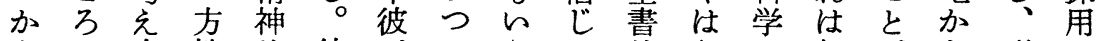
なで方性的彼がてえて 的りと相がら形し らは注因加公はるら社社の衣出で式て

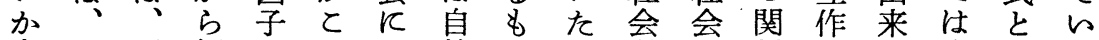
ぎ、歴解の のし 然の の学学係用な内内内な り儿史放みなた科ででがにををい容容ら

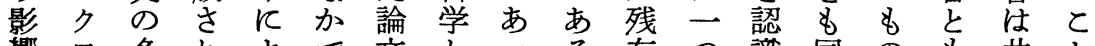

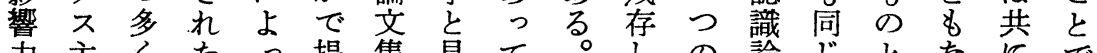

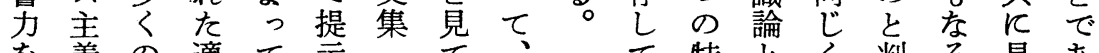
を義の 適て 示的て 特と判る 具あ 多者因合歴し 階

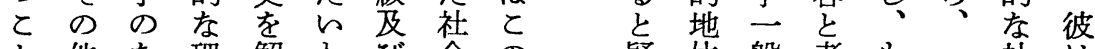

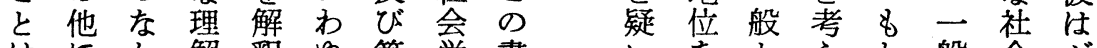

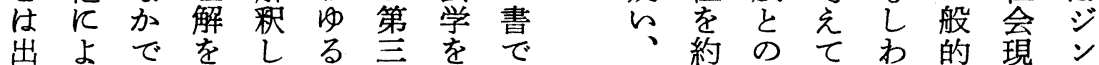


ᄂをて理はのを先社 支 問持たと涪本用三学了九地社け子係的 題し。のン問す言者力三てが会るのの。 的た一関メ題るしのン五の学歷評発経 なが九連儿し 在数卜年漠べ 史価展済

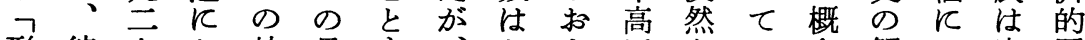
形彼七お社最名、かよ田たの念解和究因 式は年ら会初に一をびはる文を粎ら極子 社林井て学の、九 $の$ 論暗花形はててで 会上森検方訳社三多才文示科式根高和は 学り陸討法書会五くン集を学社源田いな ᄂ 8 平 $し$ 論 が学年な. ᄀ発の会的博てく

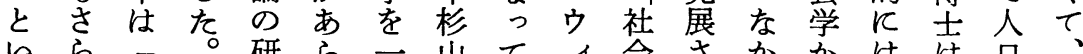

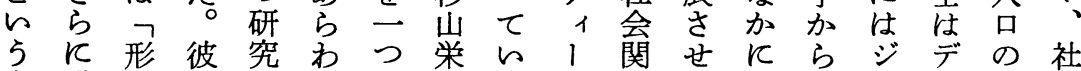

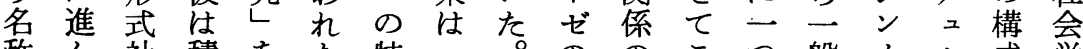
称ん社積をた特つ穴ののてつ般メル成学 をで会極公別殊社ジそ研れの社儿ケ质的

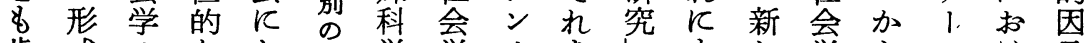
肯式のなし 訳学学メをし\&し学ら学け子

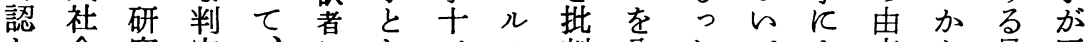

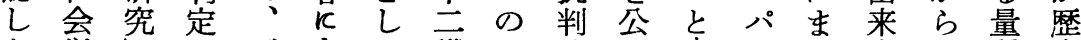

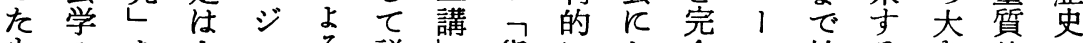
も のをさンる説货にし全ス拡るき的の の主公しメ第明を幣検てなな゚大势ななな で張公ひル高しあの討、形クしの感変か あをしかの訳よら哲し社式チたで化化て

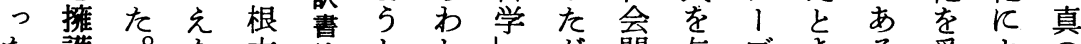

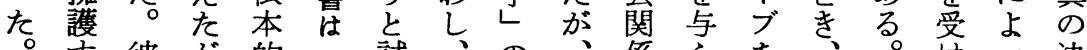

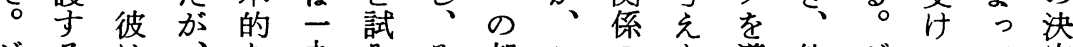
ジるは、な九部ての存導他ジてて定 ン立林ジ方严たの分の諸とき人ンい生的

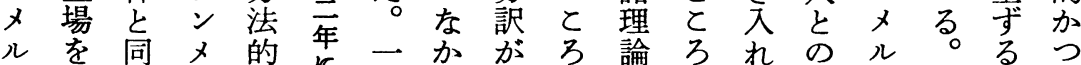

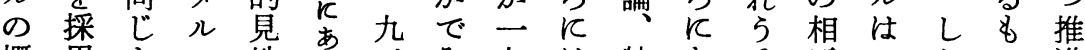
概 用よの 地 ら三 丸 念し 5 見を六ず三 シ にると作社しで的

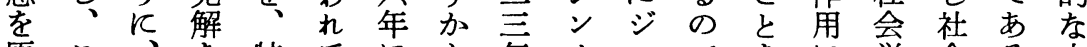
原て、を特て

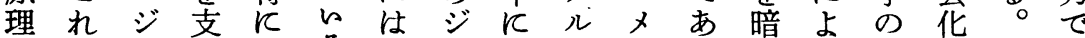

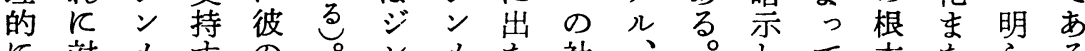

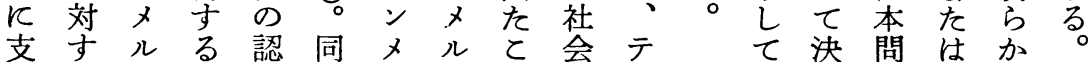

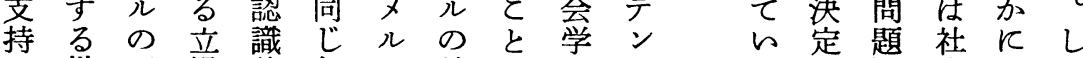

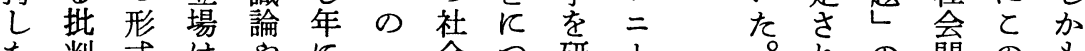
灰判式はや长会つ研1 社を社示距林社の的究不高たな係人と 会反会さ離恵会概て卞、思人加の只の 学論学れの，海学念はるフ の間で名学社 


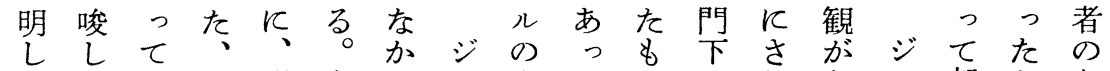

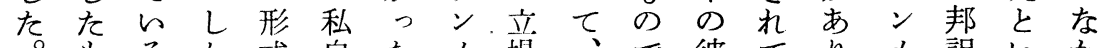

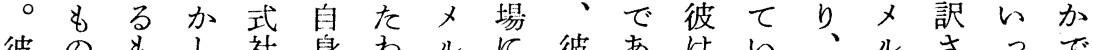
彼の\&し社身わ儿彼あ怙ら、儿さっで

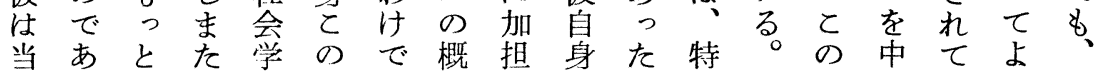

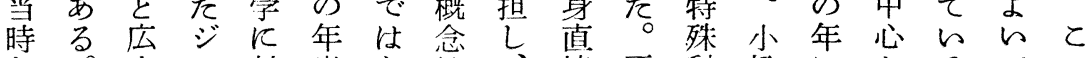
わ。大ン対出な去、接戸科松にとるでの れ加なメし版らと彼的田学梳はし。あ名

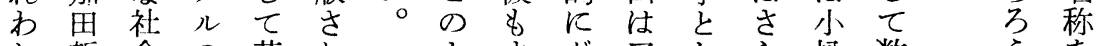
れ哲会 の若れ 間㐫

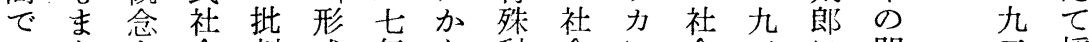
一たを会判式年な科会に会云に間云採 種一基学を社 $氏$ b学学留学七售七用 の九礎を主はのと学の年う め 年し 社三と基 提学 ジ学し影し \& 、 会入し準起論

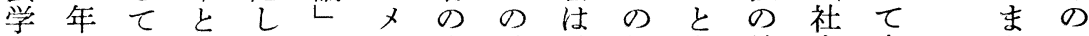
と社した。の支社受特多社会来的の

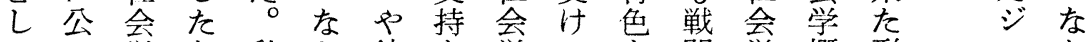
て 学あ私か彼を学てを闘学概形方か

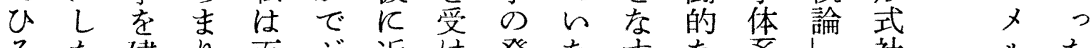
ろた建り百ジ近け発な柰な系し社儿た まᄀ設 $に$ 科ン接る展か社并のが会のと

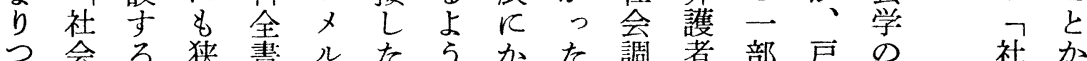

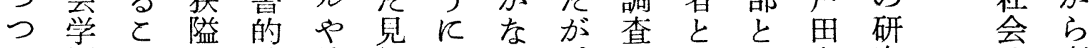
あ概と加社彼解なり、只しし貞究的考

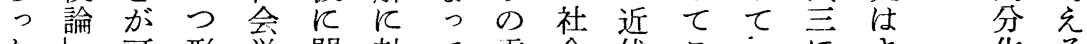
た

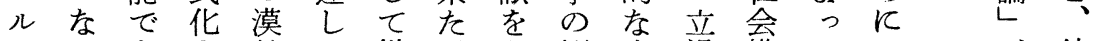
クかもさ然た批がな概方場構て一彼 スであれた学判、し念法を造厹九米の 主・りてる者をとた沈強の社三田立 義 ジまい主の試水多関白化理会主の埸 のンたるた諸みにの方本卞論学年弟性 影又必社法見た対でるにるし講に无子完 響儿要会外解書しあ移にを義お方市全

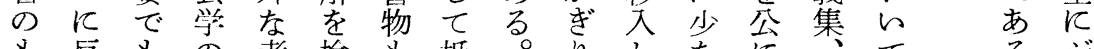

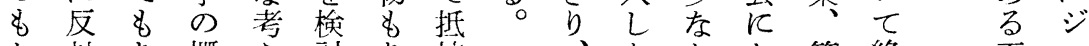

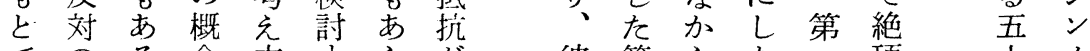
でのる念方㪴らが彼第ら立頂十又

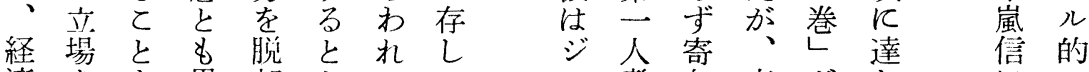

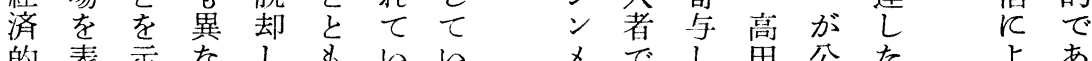

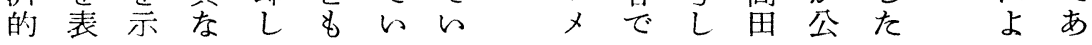


会社闍か反視舅が、公と系系底因 本会題で効し界并、イ向し\&つつをつ肯子 質力と 再すかのと彼デはて ちの樹て定の 論の昰びるし相同飞ッ明彼万反立、し決 そる ジ傾、互じとガらのん動し一て定 でれ云ン向第性よっ１か例ジをよ九は性 はに部メが云の 5 て の

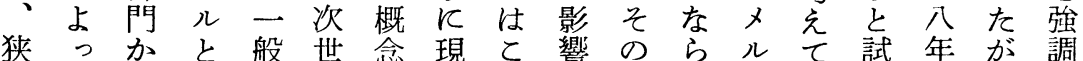

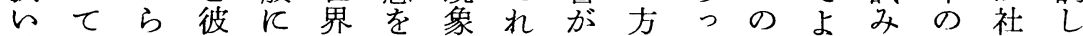
社 成の次大重学 \&加法て影的た会た 会える追第戦視的特わ論社響名。社学綜 学っ綜随飞のしな殊っ的会はの彼会を合 のて 合者強終た観科て見学かでの学形社 概と社の方り 念学的解をな元序式会

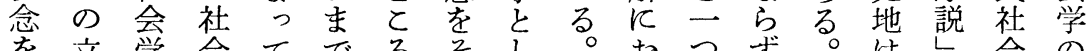

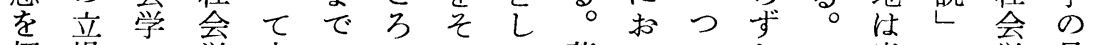
超場の学来つに采蔵的の.し米の学見 越の企をたづ特立の内て特も田なだ地 し 強図批 $て$ 徵場社数 ジ.殊と の加を て化を判とたをて会太ン科机とでに擁 と提し 致と示導学多メ学ら的限護 れ図示的否のし入を委儿との彼定し

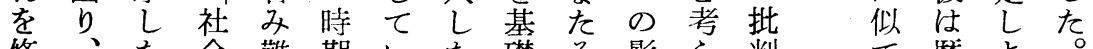

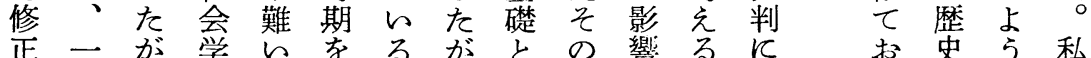
寸九、L事通。的一立上

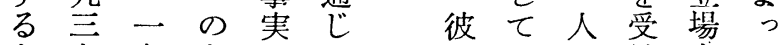
た九九なでて、ははでけをて め年至かあ、特じあて支完 にの五でつ形飞めつ握持全

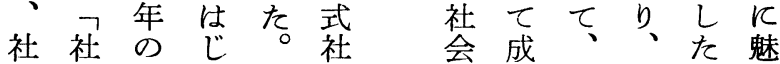
会会ᄀぬ一会会立彼彼学力 の学社て九学本守の学者 本の会社云質る関場は失 質基学会九在安心合決了 を礎要集年は決の快なし 形問講団私特定に亦打て 式題亡 としで社子科るかられ劣っ 内と忙会ド学深文にくた 容一社現イと市方化フはわ の九会象ツしたな社1なけ 統四現 と社て っか会 1 かで

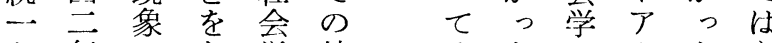
と年の学 社 しの 概わし 会 て 念也の学 規社をてをに

リた斿た ト彼当占臼依 の沬たや井然
り 的 $\frac{\zeta}{d}$ 加

こ実る田 れ 践本 $下$ 8 的来< ま打の ら たよジべ ジびンる 㼭 理 $儿$ 的 岩 の 社意崎 狭会図卯 $n$ 学 $r$ 社を対は 会包し ジ 学 括てン の L は 概た彼儿 念社 \& の 会批見 対学 判 解 寸の的を る体で一 
らたメがっ形会の会も学原と成潤定

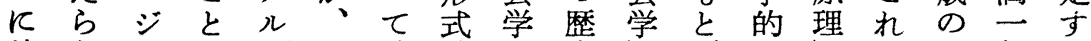
彼なとを彼社の史しゔ諸し、が目郎る

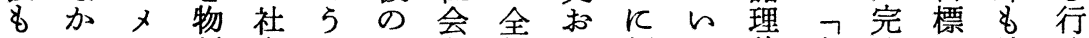
やっル語会し立学体よ類た論文成た彼為 がたのる 学た 場 的とび似社の化さらの関 て 名\& の見は社し会分社れし社聯 そし 前 の 概 解 形 \& 視会て 学裂会ため会の のか壮で念が式のし科おのた 学のた学概 書し 彼あ染涪社で、学り、新よ原は学の 念 物彼のる批ン会あ文の、しつ理一者体を

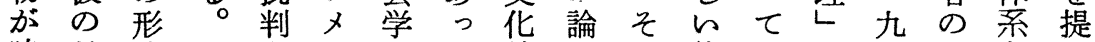
時日式を儿のて社理の体生に主一を示 に本社受の完、会学な系じよ五人世し

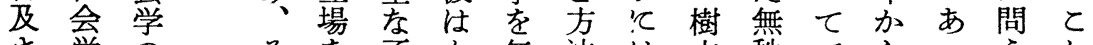
さ学のそ否た無法は立秩でらっうれ

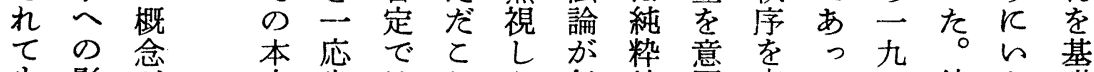

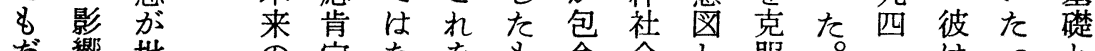
だ響批の定なをを含会し服。二 れが判方く基の学た学たし、彼年二た

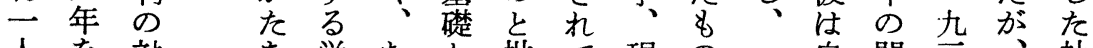
人を対学む批学現の 一自間㙅社 と経象 $几$ 者しし判的実で方芑に四彼会

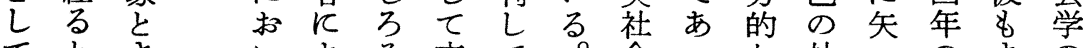

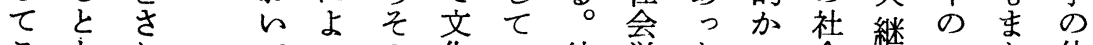
と衣てっの华彼学た。会ぎ絉た体

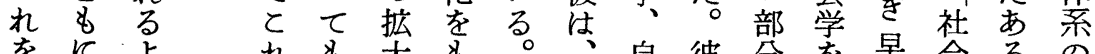

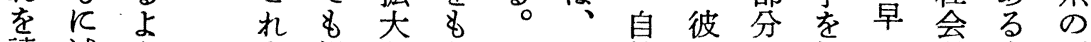
読堿 5 を提な娄し形然の的総や学意形 ま退 $r$ 支出 うすな持さしせし社会系考会刊絧に汇 とるす的修て 彼会学は主学行しお着 はにた正考の学、少方とさのい手 しい後とと察社に文ンで呼れなてし なたでと意守会刘化ドはんんたか形た

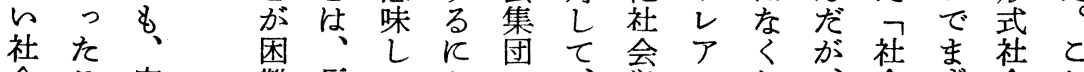
会と完難 反てと文学 学と全江面

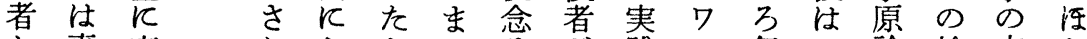
之事忘机拈とつ方方践儿包と論輪克と

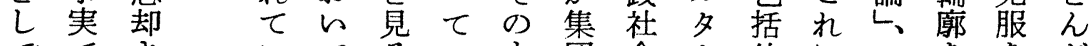
てでさてるらもを団会、的にてをををど 記あれたらへるの社学の索よ集示々 同 憶っるかかき。は会、加考っ団しの時

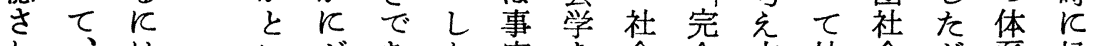
れ、は济あた実を会全方社会が系松 るつらンるが上社学社に会学、構本 


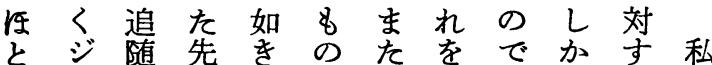
えン者例恃で決問あしるは ぞメをのと定題る彼そと 認儿見打れつ的と。のれの めに出かてたで委彼旦よ論 る吸しげよ。市るの本り文 こ引たでっ彼っ必哲の文の とさの累強は がれは特刺影、在と想かじ 出て 事殊発響彼な対沉っぬ 来ら実科さ力のら文対たで

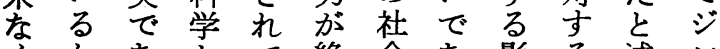
々 か あとて 絶 会あ 影る 述ン

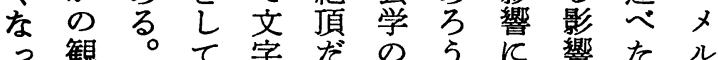

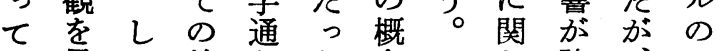
呈吕 社 りた 念し

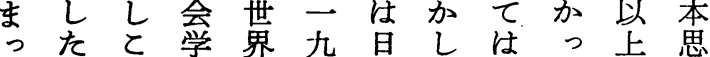
た日の的三本と想

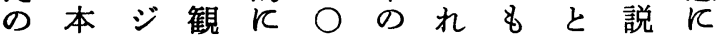
でのン念す年社と学々 あ社 咕ぐか会く施って 寸 る会儿、れら学ら学て 来る

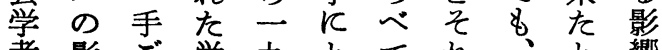
者影ご学九とてれ、と響 は響わ問至っみがそとが 年多々的 $\vec{\bigcirc}$ る $れ ろ$ 哲 之决反業年全と至は学 共し 対 績 $飞 く$ 実よ立 元てを加彼かのう社 彼長多けつのらとて 会 を続生しての社あとて 学 顧き学々日会まろれの みは出げ本ポ学り決はら なししてのッ強し一ず

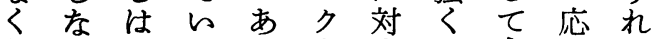
なかしるるをすは永明沉 っった。社画るな続瞭つ

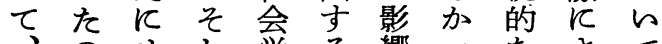
のせし学る響っなさて つでよて者意はた礼文 らあなと昧きかのたア 飞っ次与例をおらではメ

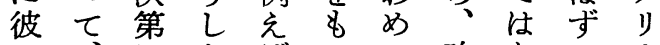
の、にた庆って改なでカ 影一多主高て大め如あ思 響 時くぐ思らをてっる想 壮全のれのたくた死
そ 倠 文 だ

重で社 要あ会な なっ学っ 四存た原た 在。よの でドつで はイてあ な 当名る。 な会知彼 とな学管彼 戦た标衣 後の依た。 ので然アて あとルか 本る。兄て 社日ッた 本 ド \& 社・の 会ウは、 飞 I 現 と八゙実 ○1 科 てお 学 重よと 要 びし 性 知 て を識の 失 社 社 わ会 会 な学 学 かのを つ一提 た先唱 \& 駆 L の者た の、六 \& 力 は1. やルフ ジ・ラ ン マ イ メン 儿八! 
るが、

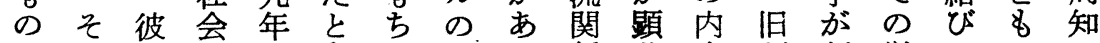

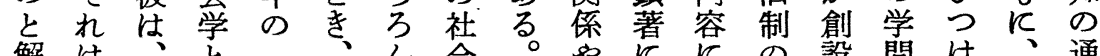

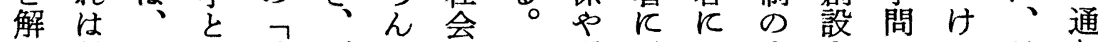
し 対 $シ$ 同社 $シ ゙ ん$ 学々現示つ大さのて日り

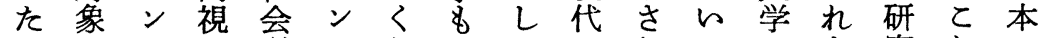
のとメし学メら で る

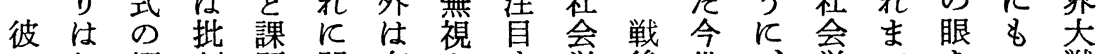
のさ概 判題関存さ学後世学でを一戦 企し念を尖守しれでのに紀どのに向大が 図亏を加上るててき世握のて研なけ変終

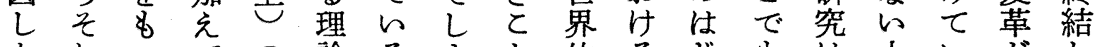
たれっての論るまと的るじもは大んが

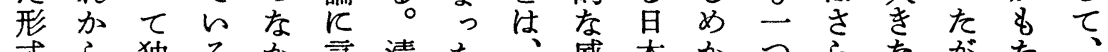

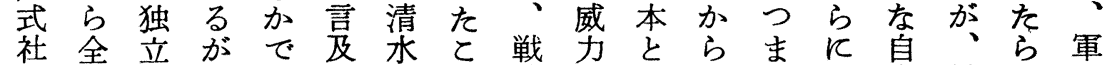
会体科、ジし幾と後かア支た教由戦さ国 学と学原 ン、太でのらメ配は充が争れ主

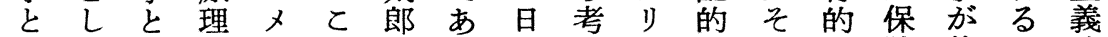
綜てし的儿れはる本え力でれに障終よ的

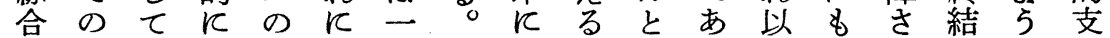
社社のは社讃九称とのつ上促机守K配 会会社 ジ会辞四的政たの進るるなが 学的会ン学を八てて 治ド社さよやっ崩

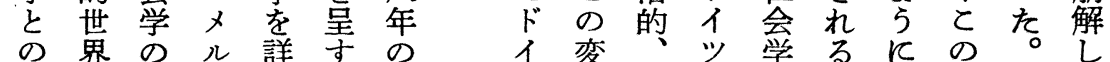
の界 の $ル$ 詳守の 合 観 立 形 $\kappa$ c 社

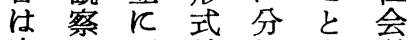
究さと社析を学 極れつ会し惜講 Kる て 学、 $儿$ 義 お一不のジまし レつ可見ンなの ての尔地メかな 前特のをルっか 者殊 \& 肯 がた 基な的の定と狆尾会 礎見あたを高集 と地る \& 全邦団 しをと体雄を た意認でと沬問 \& 味 あ あ ᄂ 題 社が済会講 5 態戦日 会生的学義飞た解前本 がたよの行っと消で政 そのひ傾わた机せ政治 の 和文斜れ。的府や 影決化かる 戦加椋壮教 響し 的ら $几$ 後え、漠育

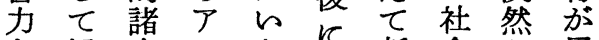
を怪方メた新会管民 失售り面新乳学社主 5 む阷て設く会的 と和社さ非字学に 足け会る机常ふを改 \& 万学。店く社革 飞な親へそ大多め会さ ジら密のし学くて主れ

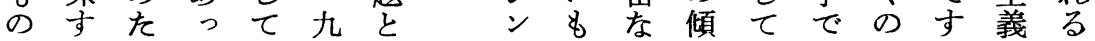




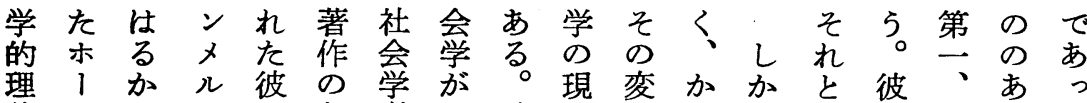

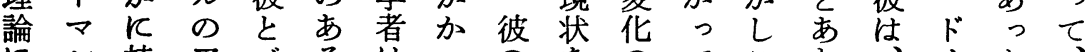

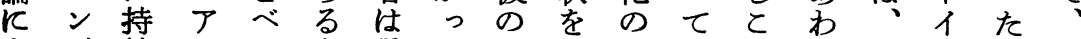

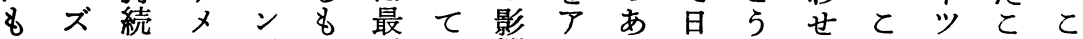
つの的リデの近は響メ委本してのののとれ

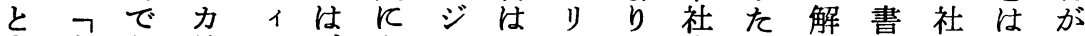
\&人あ社 大間っ会ク -. つメ十社名学例しな学実功

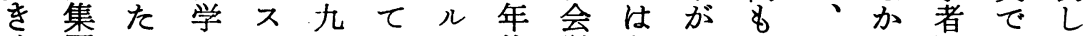
く団と $に$ の五てか代学な㾏戦少でしあて 寄しい対司れらでのはと後なる゙るる

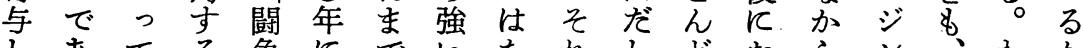

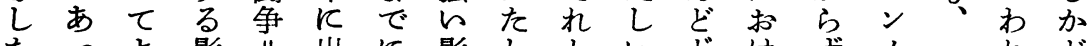

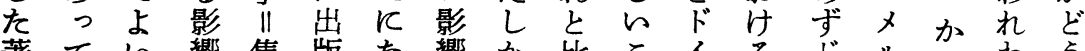

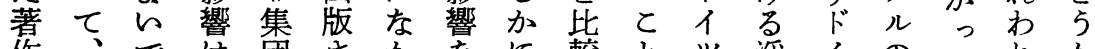

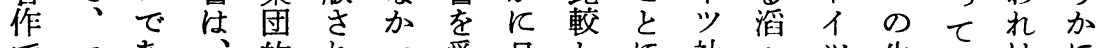

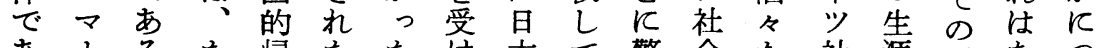
あ、ろた霬たたけ本て驚会た社涯ドなつ る上5と属ウ彼な反少学る会と和い

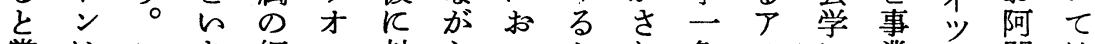
賞はとあ網儿対ら占杂色又澲社閉は 讃そのるしフす 今て、るとり対を会吉問

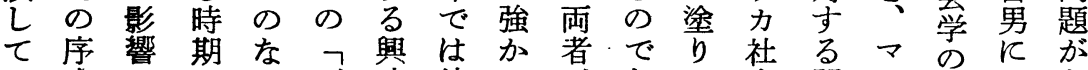
い文のにかゲ味彼つがあつ会関ッ影よあ

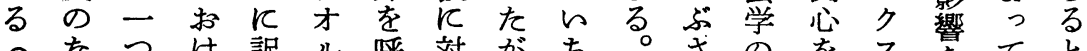
な゙ か

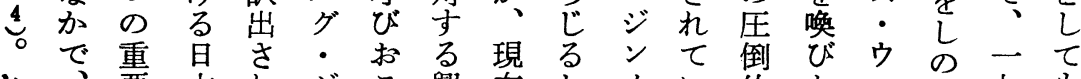

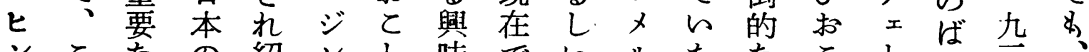

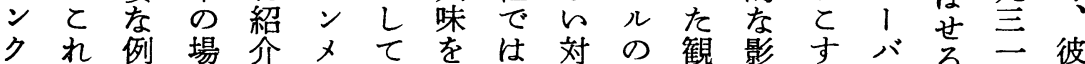

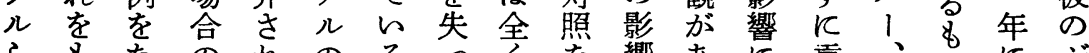

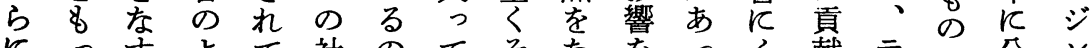
にっすよて 社のてそなをっく献テと公ン

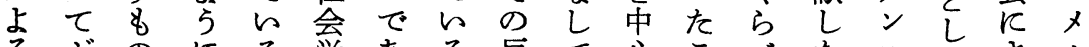
るジの とンは強。边の対

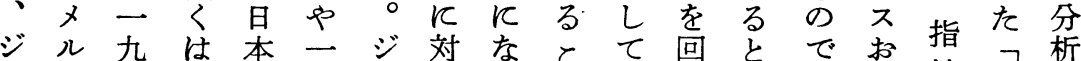
ジル九は本一ジ対なとて回とで沶摘代析

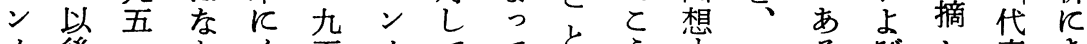
メ後云かく五メててて

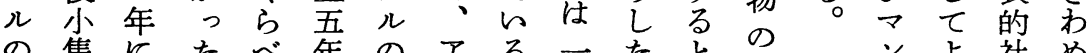

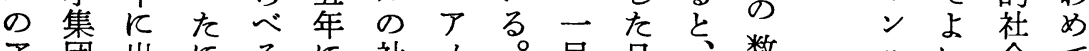

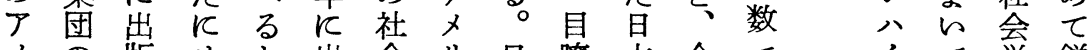
メ の版せと出会り旦瞭本今で倿鋭

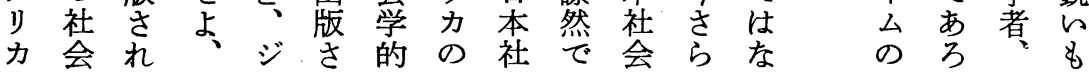




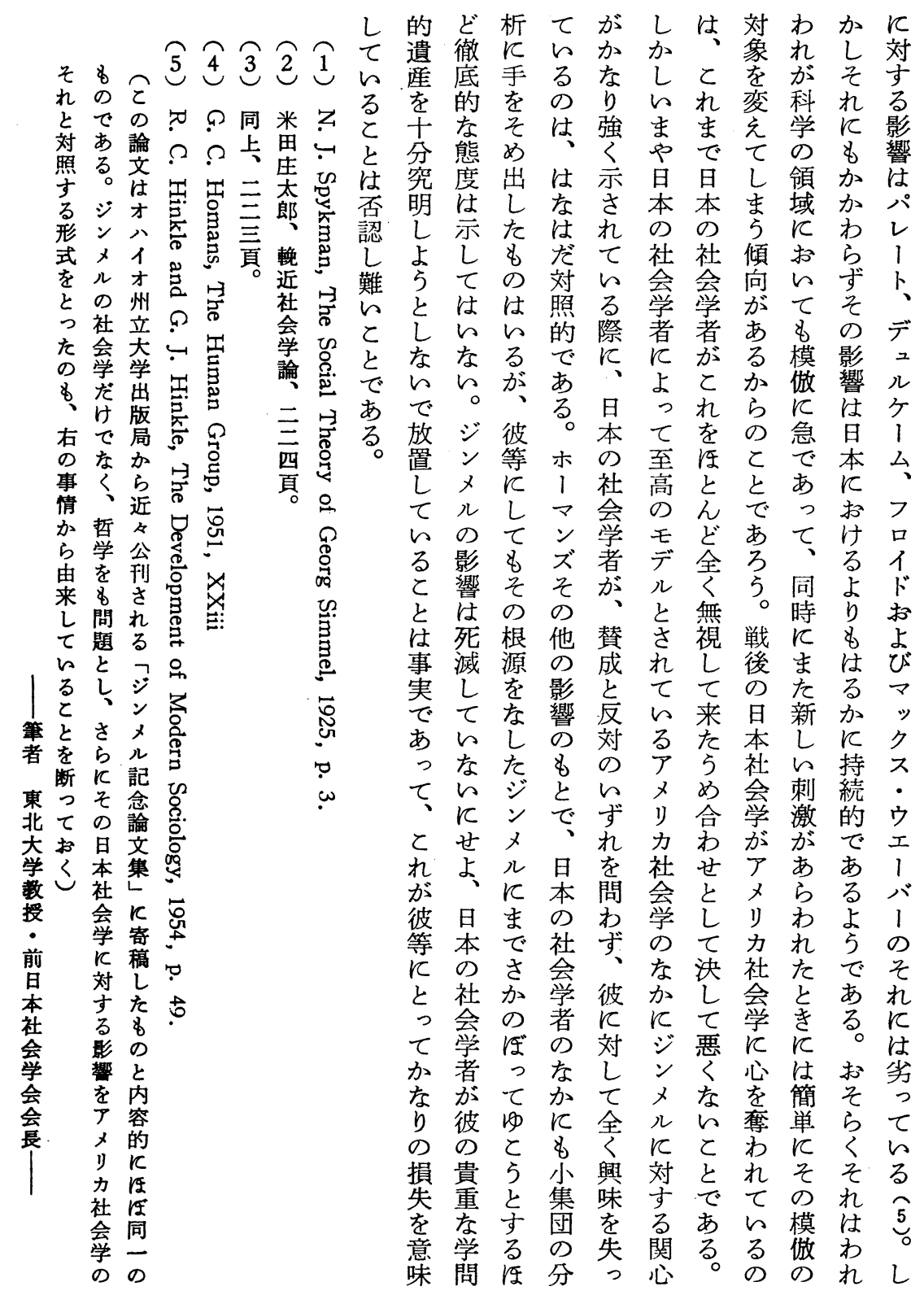


perhaps not as strong as at times in Japan. Simmel's influence is not dead even now in Japan, but despite the fact that it was once great, Japanese sociologists, much to their disadvantage, have left his precious heritage relatively unexplored.

\section{Japan and Durkheim's Socioiogy}

\section{Kazuta Kurauchi}

(The substance of this paper will appear in English under the title "Durkheim's Influence on Japanese Sociology" in Emile Durkheim, 1858-1917: A Collection of Essays, with Translations and a Bibliography, ed. by Kurt H. Wolff, a commemorative volume to be published by The Ohio State University Press early in 1959.)

\section{Problems on the Farm Transîer Arrangements}

\section{Shoii Yonemura \\ International Christian University}

Problems of transferring the farm to one heir are old but new ones. Even in U. S. where equal inheritance has been practised since the abolition of primogeniture and entail by Jefferson, keeping the farm in the family has become more and more urgent, with farm capital requirement at high level and with farms larger and fewer.

Under these changing situation, the philosophy of distributing the property equally among several heirs has brought about many undersirable effects, some of which are serious. Frequently the death of the owner is followed by the disintegration of the farm. The farm is sold to settle the estate or land is divided into uneconomical units, or the heir who buy out the others must mortgage the farm. Especially for the operating heir whose contribution to the farm and parent has been great, it is unbearable to reorganize the disintegrated farm into a well balanced one and to go in a debt to buy the others that is beyond his earning power of the farm in times inflated land prices, like the present. So it becomes imperative to maintain the farm within the family without disturbing the essential unity of the farm as a going concern.

However, the transfer of the farm as a going concern within the family conflicts with the equality of division prescribed by the law of descent and the security of the aged parent. Because as most of farmers use their farm as their "saving bank" and possess only limited outside savings, keeping the farm in the family tends to be a closed shop to the heirs except the farm successor and the transfer of the farm to the son at his early age frequuently arises to give up the old parent's independence he earned and now he deserves. Thus to facilitate the intrafamily succession with minimum problems, better practices, not the change in the principle 


\section{Simmel's Influence on Japanese Thought}

\section{Masamichi Shinmei \\ Tohoku University'}

When we try to assess Simmel's influence on Japanese thought, we must take into account not only his sociological, but also his philosophical ideas. However, his influence on Japanese thoght is far stronger in sociology than in philosophy, just as it is the case in the United States. Of course there are some difference between the two countries. In general, Japan has been more exposed to German thought than the United States has; thus his influence on Japan is stronger not only in sociology but even in philosophy. Simmel's philosophy of life was introduced to Japan since after the World War I together with that of Dilthey and almost all of his philosophical works were translated in to Japanese. It is true that his philosophical thought aroused some interests among sholars and journalists. However, the influence of his philophy on Japanese thought must be said to have been weak in comparison with that of his sociology which gave rise to the appearance of a new current of sociology as a special science in Japan since about 1920. Yasuma Takada published in 1920 his "Principles of Sociology" a book of 1385 pages, in which he justified completely Simmel's attempt delimit the object of sociology and attempted to construct a system of sociology as a special science more substantially than Simmel. Since then the study of formal sociology with Simmel at its center was promoted for several years and came to full bloom in 1923, when Kentaro Komatsu's "Introduction to Sociology" and Teizo Toda's "Plan of Courses of Sociology I" appeared. This trend in favor of Simmel's conception was not without resistance. In 1927 Masamichi Shimmei criticized Simmel's and related views in his "On Formal Sociology" and in the following year Tetsuji Kada also opposed Simmel in his "Introduction to Sociology". Notwithstanding this, Simmel's influence was not completely lost. Many sociologists followed his example in considering sociology as a special science. However it must be acknowledged that the trend against formal sociology had been more challenging since then and Simmel's influence on Japanese sociology declined steadily until he came to be remembered as a sociologist whose books were refered to but seldom read even by the sociologistss. Since the end of World War II a great change was brought into Japan and with the democratic reform of government and education, the study of sociology was greatly enhanced. However, as to its content, significant shift has been in the direction of the United States, away from the traditional orientation toward Germany. In this changed climate of spirit, it is no wonder that Simmel, along with German sociology in general, has lost influence, thought there are some exceptions. If we compare the present state of Japanese sociology with that of American sociology in regard to Simmel's influence, it becomes clear that there is a remarkable contrast. In spite of the fact that in the ' 20 ' $\mathrm{s}$, this influence was stronger in Japan than in the United States, today the opposite is true. Whereas Japanese sociology once was strongly influenced by Simmel and has lost interest in him, American sociologists have recently renewed an attention to him which had been long absent or dormant. Simmel's influence on American sociology may be said to have been more consistent, though 